\title{
HUBUNGAN ANTARA DUKUNGAN KELUARGA DENGAN KEJADIAN KEKAMBUHAN (RELAPS) PADA PENYALAHGUNA NARKOBADI RUMAH DAMPING TENJO LAUTKABUPATEN KUNINGAN TAHUN 2016
}

\author{
THE RELATIONSHIP BETWEEN FAMILY SUPPORT TO EVENTS THE RELAPSE OF \\ DRUG ABUSERS AT RUMAH DAMPING TENJO LAUT IN KUNINGAN DISTRICT 2016
}

\author{
Aria Pranatha ${ }^{1}$, Rika Rostika ${ }^{2}$
}

\begin{abstract}
ABSTRAK
Penggunaan obat-obatan secara sipil telah ada di setiap tahun, pada tahun 2008 ada 3.362.527 orang yang menggunakan narkoba kemudian menjadi 5.126.913 pada tahun 2015. Penyalahgunaan obat telah direnovasi dan disembuhkan diizinkan untuk menggunakan narkoba (kambuh). Laporan ini bertujuan untuk meninjau kembali hubungan antara suport keluarga dengan Peristiwa kambuh pelaku narkoba di rumah meredam tenjo laut di kabupaten kuningan 2016.

Jenis penelitian yang digunakan adalah desain analitik cross sectional. Instrumen yang digunakan adalah kuesioner yang telah mengalami validitas ada 15 responden, uji validitas menunjukkan bahwa dukungan untuk keluarga 23 pertanyaan 4 tidak valid karena nilai $r$ kurang dari $r$ tabel $(0,514)$. Pelaksanaan penelitian ini pada Mei 2016. Sampel 40 responden menggunakan total sampling dan data analisis menggunakan chi square.

Berdasarkan pengolahan data diperoleh dukungan keluarga terhadap kategori baik yaitu sekitar (52,5\%) dan kekambuhan mayoritas responden mengalami kekambuhan yaitu sekitar (65\%). Dari analisis hubungan keluarga kekambuhan (kambuh) terhadap pelaku narkoba di Rumah Damping Tenjo Laut di Kabupaten Kuningan 2016 adalah p value 0,026 .

Kesimpulannya ada hubungan positif antara suport keluarga terhadap kejadian kambuh pelaku narkoba di rumah redaman tenjo laut di kabupaten kuningan 2016. Diperkirakan supervisi dan bantuan mantan pengguna narkoba harus lebih optimal untuk mengurangi kejadian kambuh dan penyalahgunaan narkoba bisa hidup sehat tanpa narkoba.
\end{abstract}

Kata kunci: Dukungan Keluarga, Kambuh

\section{ABSTRACT}

The civil using drugs in indonesia has been increasing every year, in 2008 there are 3.362.527 people drugs abusers later became 5.126.913 in 2015. There were 51 cases of drug abuses in kuningan district in all 2015. Drugs abusers have renovated and healing allowed to use drugs ( relapse ). Cause a recurrence can be caused by several factors that may be one of these factors family. This report aims to review the relationship between family suport to events the relapse of drugs abuser at rumah damping tenjo laut in kuningan district 2016.

The kind of research use is analytic design cross sectional .Instrument used is a questionnaire that has undergone a validity there are 15 respondents, test validity suggests that support for the family of 23 questions 4 are not valid and variable a recurrence of 20 questions 8 invalid because the value of $r$ less than the $r$ table $(0,514)$. The implementation of this research on may 2016 . The sample 40 respondents were using a total sampling and analysis data using the chi square. Based on data processing obtained a family support of good category that is about ( $52,5 \%$ ) and a recurrence the majority of respondents experienced a recurrence that is about (65\%). From an analysis of the relationship between a family of a recurrence (relapse) on drugs abusers at Rumah Damping Tenjo Laut in Kuningan District 2016 is $p$ value 0,026 .

The conclusion is there a positive relationship between family suport to events the relapse of drugs abuser at Rumah damping tenjo laut in kuningan district 2016. Expected supervision and assistance former drug users must be more optimal to reduce incidence a recurrence and drugs abusers can healthy life without drugs.
JURNAL

SKOLASTIK KEPERAWATAN

Vol. 3, No.1

Januari - Juni 2017

ISSN: $2443-0935$

E-ISSN: 2443 - 1699 
Keywords: Family Support, Relapse

\section{PENDAHULUAN}

Narkoba atau Napza (Narkotika, Psikotropika, dan Adiktif lainnya) merupakan sekelompok obat, yang berpengaruh pada kerja tubuh, terutama otak. Fenomena penyalahgunaan narkoba ibarat gunung es, hanya sedikit yang terdeteksi tetapi banyak yang belum terungkap. Penyalahgunaan narkoba dapat memberikan berbagai dampak negatif bagi penggunanya, seperti dampak ekonomi, sosial, dan dampak kesehatan fisik serta psikis selain itu penyalahgunaan narkoba dapat merusak mental dan moralitas generasi penerus bangsa.

Penyalahgunaan narkoba di seluruh negara terus mengalami kenaikan, dimana hampir $12 \%$ (15,5 juta jiwa sampai dengan 36,6 juta jiwa) dari pengguna adalah pecandu berat Menurut (World Drug Report tahun,2012). Sedangkan menurut data United Nations on drugs and crime (UNDC) (2012), dari seluruh penduduk dunia terdapat 230 juta penduduk atau $5 \%$ pernah mengkonsumsi obat-obatan terlarang setidaknya satu kali seumur hidup.

Menurut phadli (2015) kasus penyalahgunaan narkoba di Indonesia dari tahun ke tahun juga terus mengalami kenaikan dimana pada tahun 2008 ada sebanyak 3.362.527 jiwa penyalahguna narkoba dengan pravalensi 1,99\%, pada tahun 2011 sebanyak 4.071.016 dengan pravalensi 2,3\%, pada tahun 2013 sebanyak 4,9 juta dan terus mengalami kenaikan pada tahun 2015 diperkirakan 5.126.913 dengan pravalensi $2,8 \%$.

Propinsi Jawa barat mejadi daerah tujuan peredaran narkoba setelah Jakarta sekaligus menjadi target pemasaran yang bagus, hal ini dapat dilihat dari data BNNP Jawa Barat (2015) menunjukan tingkat prevalensi yang pernah memakai narkoba tahun 2013 sebesar 5,9\% $(1.898,231)$ dari total jumlah penduduk sebanyak 33.173.414 orang, sedangkan penyalahguna narkoba pada tahun 2014 sebanyak 792.206 orang. Berdasarkan data yang diperoleh dari BNN Kabupaten Kuningan (BNNK) (2016) jumlah penyalahguna narkoba di Kabupaten Kuningan dari tahun ketahun juga terjadi peningkatan ditandai dengan kasus penyalahgunaan narkoba pada tahun 2013 sebanyak 20 kasus, pada tahun 2014 menjadi 34 kasus dan pada tahun 2015 terdapat 51 kasus penyalahgunaan narkoba.

$\begin{array}{llr}\text { Menurut Badan } & \begin{array}{c}\text { Narkotika } \\ \text { Kabupaten }\end{array} & \text { Nuninganal } \\ \text { Penyalahgunaan } & \text { Narkoba } & \text { mempunyai }\end{array}$ dampak yang sangat luas bagi pemakainya (diri sendiri), serta masyarakat, bangsa dan negara. Upaya penanggulangan penyalahgunaan narkoba bersifat komperhensif, untuk itu bagi pecandu atau penyalahguna, Undang-undang telah memberikan hak bagi mereka untuk mendapatkan rehabilitasi medis dan sosial. Hal tersebut berkaitan dengan pentingnya proses pemulihan dan cara pandang bahwa pengguna narkoba bukanlah prilaku kriminal melainkan hanya korban. Namun para pengguna narkoba yang telah direhabilitasi maupun sedang dalam masa pemulihan memungkinkan kembali menggunakan narkoba (Relapse). Kekambuhan (relapse) merupakan suatu kondisi menggunakan kembali narkoba setelah dilakukan upaya rehabilitasi atau upaya pemulihan. Berdadasrkan data Badan Narkotika Nasional kabupaten Kuningan (2014:52) angka kambuh di Indonesia mencapai 90\% atau 9 dari 10 pecandu telah selesai mengikuti program terapi rehabilitasi dan yang sedang mengikuti terapi rehabilitasi kembali mengkonsumi atau menjadi pecandu narkoba. Hal ini terjadi akibat respon adaptasi yang tidak berhasil karena dipengaruhi masa lalu saat masih menggunakan narkoba, selain itu penyebab kekambuhan narkoba di sebabkan oleh beberapa faktor kemungkinan salah satunya yaitu faktor keluarga. 
Friedman dalam Setiadi (2008) menjelaskan bahwa, dukungan keluarga mengacu kepada dukungan-dukungan yang dipandang oleh anggota keluarga sebagai sesuatu yang dapat diadakan untuk keluarga, dimana dukungan tersebut bisa atau tidak diadakan, tetapi anggota keluarga memandang bahwa orang yang bersifat mendukung selalu siap memberikan pertolongan dan bantuan jika diperlukan.

Menurut penelitian yang dilakukan oleh hurriyati (2011) dengan menggunakan metode study kasus didapatkan keterangan bahwa dukungan keluarga (orangtua) terhadap remaja yang menggunakan narkoba pada kedua subjek, mempersepsikan ayah bukan sebagai pemberi dukungan bahkan keduanya mempersepsikan ayah sebagai sumber konflik, Sehingga konflik dengan ayah menjadi salah satu faktor yang memicu untuk relapse. Begitu pula penelitian yang dilakukan oleh isnaini (2011) terdapat hubungan antara dukungan keluarga dengan keinginan untuk sembuh pada penyalahguna napza di Lembaga Pemasyarakatan Wirogunan Yogyakarta dengan nilai kemaknaan $\mathrm{p}=0,002$.

Berdasarkan studi pendahuluan yang dilakukan oleh peneliti di panti Rehabilitasi Narkoba Tenjo Laut Kabupaten Kuningan terhadap 5 orang respon, ternyata ke-5 Responden mengatakan pernah mencoba untuk berhenti untuk tidak mengguankan narkoba namun hal tersebut tidak berhasil dan pada akhirnya menggunakan narkoba kembali (relapse). 1 responden mengatakan bahwa keluarganya bersifat acuh tak acuh, responden merasa tidak mendapat perhatian dan tidak mendapatkan dukungan sehingga responden kembali menggunakan narkoba (relapse), sedangkan 4 responden lain mengatakan bahwa keluarga selalu mendukung, peduli serta selalu memberikan support untuk berhenti menggunakan narkoba namun responden tetap kembali memakai narkoba (relapse). Berdasarkan uraian diatas, maka peneliti merasa tertarik utuk melakukan penelitian mengenai
Hubungan Antara Dukungan Keluarga Dengan Kejadian Kekambuhan (Relapse) Pada Penyalahguna Narkoba Di Rumah Damping Tenjo Laut Kabupaten Kuningan Tahun 2016.

\section{METODOLOGI PENELITIAN}

Penelitian ini merupakan penelitian analitik dengan rancangan cross sectional yaitu untuk mengukur variabel bebas (dukungan keluarga) dan variabel terikat (kejadian kekambuhan) secara bersamaan. Responden penelitian berjumlah 40 penyalahguna narkoba yang berada di Rumah Damping Tenjo Laut Kabupaten Kuningan, dengan teknik pengambilan sampel menggunakan total sampling (Badriah, 2012).

Dalam penelitian ini teknik pengumpulan data menggunakan metode kuesioner. Dimana kuesioner bagian pertama berisi 19 pernyataan tentang dukungan keluarga, dan kuesioner bagian kedua berisi 12 pertanyaan tentang kekambuhan.

Analisis yang dipergunakan untuk melihat hubungan antara variabel bebas dengan variabel terikat, menggunakan uji Chi Square.

\section{HASIL PENELITIAN}

\section{Analisis Univariat}

Tabel 5.1 Distribusi Frekuensi Dukungan Keluarga Pada Penyalahguna Narkoba Di Rumah Damping Tenjo Laut Kabupaten Kuningan Tahun 2016

\begin{tabular}{|l|l|l|l|}
\hline No & $\begin{array}{l}\text { Dukungan } \\
\text { Keluarga }\end{array}$ & $\begin{array}{l}\text { Frekuensi } \\
(f)\end{array}$ & $\begin{array}{l}\text { Perse } \\
\text { ntase } \\
(\%)\end{array}$ \\
\hline 1. & Baik & 21 & 52,5 \\
\hline 2. & Kurang Baik & 19 & 47,5 \\
\hline Total & 40 & 100 \\
\hline
\end{tabular}

Sumber : Hasil Penelitian Tahun 2016 
Berdasarkan tabel 5.1 diatas, dapat diketahui bahwa dari 40 responden lebih dari setengahnya responden memiliki dukungan keluarga yang baik yaitu sebanyak 21 responden $(52,5 \%)$

Tabel 5.2 Distribusi Frekuensi Kejadian Kekambuhan Pada Penyalahguna Narkoba Di Rumah Damping Tenjo Laut Kabupaten Kuningan

\begin{tabular}{|c|c|c|c|}
\hline No & $\begin{array}{c}\text { Kejadian } \\
\text { Kekambuhan }\end{array}$ & $\begin{array}{c}\text { Frekuen } \\
\text { si (f) }\end{array}$ & $\begin{array}{c}\text { Pers } \\
\text { enta } \\
\text { se } \\
(\%)\end{array}$ \\
\hline 1. & Tidak kambuh & 26 & 65 \\
\hline 2. & Kambuh & 14 & 35 \\
\hline \multicolumn{2}{|c|}{ Total } & 40 & 100 \\
\hline
\end{tabular}

Sumber : Hasil Penelitian Tahun 2016

Berdasarkan tabel 5.2 diatas, dapat diketahui bahwa dari 40 responden sebagian besar responden tidak mengalami kekambuhan yaitu sebanyak 26 responden $(65 \%)$

\section{Analisis Bivariat}

Tabel 5.3 Hubungan Antara Dukungan Keluarga Dengan Kejadian Kekambuhan (Relapse) Pada Penyalahguna Narkoba Di Rumah Damping Tenjo Laut Kabupaten Kuningan

\begin{tabular}{|c|c|c|c|c|c|c|c|}
\hline \multirow{3}{*}{$\begin{array}{c}\text { Dukun } \\
\text { gan } \\
\text { Keluar } \\
\text { ga }\end{array}$} & \multicolumn{4}{|c|}{$\begin{array}{c}\text { Kejadian } \\
\text { Kekambuhan }\end{array}$} & \multirow{2}{*}{\multicolumn{2}{|c|}{ Total }} & \multirow{2}{*}{$\begin{array}{c}P \\
\text { val } \\
\text { ue }\end{array}$} \\
\hline & \multicolumn{2}{|c|}{$\begin{array}{c}\text { Kamb } \\
\text { uh }\end{array}$} & \multicolumn{2}{|c|}{$\begin{array}{c}\text { Tidak } \\
\text { Kamb } \\
\text { uh }\end{array}$} & & & \\
\hline & $F$ & $\%$ & $F$ & $\%$ & $F$ & $\%$ & \\
\hline Baik & 4 & 19 & $\begin{array}{l}1 \\
7\end{array}$ & 81 & $\begin{array}{l}2 \\
1\end{array}$ & $\begin{array}{c}10 \\
0\end{array}$ & 0,0 \\
\hline $\begin{array}{l}\text { Kuran } \\
\text { g Baik }\end{array}$ & $\begin{array}{l}1 \\
0\end{array}$ & $\begin{array}{c}52 \\
5\end{array}$ & 9 & $\begin{array}{r}47 \\
5\end{array}$ & $\begin{array}{l}1 \\
9\end{array}$ & $\begin{array}{c}10 \\
0\end{array}$ & 26 \\
\hline Tot & $\begin{array}{l}1 \\
4\end{array}$ & 35 & $\begin{array}{l}2 \\
6\end{array}$ & 65 & $\begin{array}{l}4 \\
0\end{array}$ & $\begin{array}{c}10 \\
0\end{array}$ & \\
\hline
\end{tabular}

Sumber : Hasil Penelitian Tahun 2016
Berdasarkan tabel 5.3 dapat diketahui bahwa responden yang memiliki dukungan keluarga baik cenderung tidak menggunakan narkoba kembali (relapse) yaitu sebanyak 17 responden (81\%), sedangkan responden yang memiliki dukungan keluarga kurang baik cenderung menggunakan narkoba kembali (relapse) yaitu sebanyak 10 responden (52,5\%). Hasil uji statistik chi square didapatkan $\mathrm{p}$ value 0,026 . Maka hipotesis yang diajukan di bab 3 dengan bunyi "terdapat hubungan yang positif antara dukungan keluarga dengan kejadian kekambuhan di rumah damping tenjo laut kabupaten kuningan tahun 2016" dapat dibuktikan dengan hasil penelitian atau dengan kata lain hipotesis sejalanan dengan hasil penelitian.

\section{PEMBAHASAN PENELITIAN}

\section{Gambaran Dukungan Keluarga Pada Penyalahguna Narkoba Di Rumah Damping Tenjo Laut Kabupaten Kuningan Tahun 2016}

Berdasarkan tabel 5.1 diatas, hasil penelitian menunjukan bahwa, sebagian besar responden memiliki dukungan keluarga yang baik yaitu sebanyak 21 responden (52,5\%). Berdasarkan hasil interpretasi selama penelitian, peneliti berpendapat bahwa mayoritas penyalahguna narkoba memiliki dukungan keluarga yang baik, keluarga dapat menerima anggota keluarganya yang mengguanakan narkoba dan mampu mendukung anggota keluarga dalam melakukan upaya pemulihan dukungan tersebut berupa dukungan dukungan informasional, dukungan penilaian, dukungan instrumental dan dukungan emosional.

Friedman dalam Setiadi (2008) menjelaskan dukungan keluarga merupakan sebuah proses yang terjadi sepanjang kehidupan, dimana dalam sebuah tahap siklus kehidupan, dukungan keluarga membuat keluarga mampu berfungsi dengan berbagai situasi sesuai dengan kepandaian dan akal untuk meningkatkan derajat kesehatan keluarga dan adaptasi keluarga dalam 
kehidupan. Sehingga dukungan keluarga mampu mendatangkan rasa senang, rasa aman, rasa puas dan rasa nyaman. Dukungan keluarga berkaitan dengan pembentukan keseimbangan mental, prilaku, dan kepuasan psikologis.

Menurut BNN Kabupaten Kuningan (2012:13), menjelaskan bahwa keluarga merupakan bagian terpenting dalam proses kehidupan seseorang, begitupun dengan para penyalahguna narkoba yang membutuhkan dukungan yang lebih dari keluarga khususnya orangtua. hubungan yang kurang dekat antara orangtua dan anak atau kurang komunikasi menyebabkan anak mencari pengganti dan menggantinya masuk ke dalam teman kelompok sebaya, dimana anak mulai berkenalan dengan narkoba.

\section{Gambaran Kejadian Kekambuhan (Relapse) Pada Penyalahguna Narkoba Di Rumah Damping Tenjo Laut Kabupaten Kuningan Tahun 2016}

Berdasarkan tabel 5.1 diatas, hasil penelitian menunjukan bahwa, sebagian besar responden tidak mengalami kekambuhan yaitu sebanyak 26 responden (65\%) menurut BNNP Jawa Barat (2015:45) menjelaskan bahwa kambuh (relapse) murupakan suatu kondisi mantan pengguna narkoba yang sudah sempat bersih namun kembali mengkonsumsi narkoba. Hal tersebut dapat dipengaruhi oleh beberapa faktor, seperti faktor individu penyalahguna narkoba itu sendiri, faktor lingkungan, faktor keluarga dan faktor pengetahuan.

Dalam hasil penelitian ini menunjukan bahwa sebanyak 65\% penyalahguna narkoba yang berada di rumah damping tenjo laut kabupaten kuningan tidak mengalami kekambuhan, hal tersebut berarti cukup banyak penyalahguguna narkoba mampu untuk tidak menggunakan narkoba kembali. Menurut Isnaini (2009) menjelaskan usaha pecandu untuk lepas dari belenggu napza merupakan perjuangan hidup yang dapat dikatakan seumur hidup, karena hampir seluruh dimensi pecandu telah rusak oleh kekacauan yang diakibatkan oleh kecanduannya sehingga para penyalahguna harus waspada terhadap kemungkinan terjadinya relapse, yaitu kembali menggunakan napza dengan pola yang sama. Salah satu usaha untuk memperkuat penyalahguna untuk dapat hidup bersih dari napza adalah dengan adanya dukungan keluarga ( family support) selain itu dibutuhkan dukungan obat, motivasi diri, lingkungan dan rehabiitasi secara fisik, medis, sosial dan juga psikologis.

Menurut Prasetyaningsih (2008) upaya pencegahan relapse yang dapat dilakukan adalah dengan cara mencegah penyalahguna narkoba untuk tidak kembali kepada lingkungan yang berisiko tinggi, seperti bertemu dengan teman sesama pengguna narkoba atau pergi ke tempat yang pernah dipakai penyalahguna untuk memakai narkoba. Beri kesempatan kepada penyalahguna narkoba untuk mengungkapkan isi hatinya dan berikan dorongan untuk setiap tindakan yang positif. Segera atasi penyalahguna narkoba ke rumah sakit maupun ke dokter jiwa jika kekambuhan disebabkan karena depresi, kecemasan atau gangguan psikotik. Ubah gaya hidup penyalahguna narkoba pada kegiatan positif seperti mengikut sertakan dalam kegitan-kegiatan yang berada di masyarakat. Berilah dukungan dukungan emosional seperti empati, kepedulian, dan perhatian dengan mengikutsertakan peran orangtua dan keluarga, selain itu berikanlah dukungan penghargaan untuk setiap prestasi ataupun hal positif yang dilakukan karena dukungan penghargaan dapat membuat para penyalahguna narkoba menjadi lebih semangat untuk dapat pulih serta akan membuat rasa percaya dirinya meningkat. Bantu dengan dukungan instrumental seperti memberikan keterampilan dan lapangan pekerjaan ataupun melanjutakan pendidikan.

Hubungan antara dukungan keluarga dengan kejadian kekambuhan (Relapse) pada penyalahguna narkoba di Rumah 


\section{Damping Tenjo Laut Kabupaten Kuningan}

Hasil penelitian menunjukan bahwa terdapat hubungan yang positif antara dukungan keluarga dengan kejadian kekambuhan pada penyalahguna narkoba di rumah damping tenjo laut kabupaten kuningan tahun 20016 dengan nilai $p=0,026$. Hal ini dapat diartikan bahwa semakin baik dukungan keluarga terhadap penyalahguna narkoba dalam upaya pemulihan maka semakin kecil risiko penyalahguna narkoba mengalami kekambuhan. Hal ini juga di perkuat oleh Friedman dalam Setyowati (2008:29), lima fungsi dasar keluarga salahsatunya adalah fungsi perawatan kesehatan yaitu kemampuan keluarga dalam merawat anggota keluarga yang mengalami masalah kesehatan. Jadi keluarga yang mempunyai anggota penyalahguna narkoba harus mampu mengatasi masalah kesehatan dengan cara keluarga mendukung penyalahguna untuk melakukan pemulihan di panti rehabilitasi narkoba baik rehabilitasi medis ataupun rehabilitasi sosial.

Hal tersebut didukung oleh BNNRI (2009:3) yang menjelaskan bahwa faktor keluarga dalam hubungannya dengan penyalahguna narkoba memiliki keterkaitan yang sangat erat sebagai bagian dari fungsi dalam keluarga. Keluarga sebagi unit sosial terkecil dalam masyarakat dan mempunyai peran penting bagi penyalahguna narkoba. Komunikasi dalam keluarga, peran orangtua dan kondisi keluarga sangat mempengaruhi kepribadian pada anggota penyalahguna narkoba. Penyalahguna akan rentan atau tidak terhadap kekambuhan, semua tergantung kepada masing - masing anggota keluarga dalam menjalin komunikasi, mendidik serta memberikan suasana lingkungan yang kondusif.

Penyalahguna narkoba yang sedang melaksankan upaya pemulihan atau yang sudah bersih perlu mendapatkan pengawasan dari anggota keluarga yang lain. Hal ini dapat menjadi upaya pencegahan bagi penyalahguna narkoba untuk tidak menggunakan narkoba kembali. Peran keluarga menjadi sangat penting terhadap penyalahguna narkoba, keluarga diharapkan mampu memerankan perannya dengan baik sehingga tercipta keluarga yang fungsional. Ciri keluarga yang fungsional menurut BNNK Kuningan (2009) adalah minimalnya perselisihan antara orangtua dengan anak, memberikan kesempatan bagi anak untuk menyatakan keinginannya, adanya musyawarah dalam memecahkan permaslahan keluarga dan menjalin kebersamaan antara oragtua dengan anak.

Penelitian di atas juga di perkuat dari hasil penelitain yang dilakukan oleh Isnaini (2009) dengan judul hubungan antara dukungan keluarga dengan keinginan untuk sembuh pada penyalahguna napza di Lembaga Pemasyarakatan Wirogunan Kota Yogyakarta tahun 2009 hasil penelitian di dapatkan dengan uji penelitian menggunakan chi square. Hasil penelitain menunjukan distribusi frekuensi dukungan keluarga termasuk dalam kategori dukungan tinggi sebanyak (54\%), katgori dukungan keluarga sedang sebanyak (28\%) dan dukungan keluarga dengan kategori rendah sebanyak (18\%). Untuk distribusi frekuensi keinginan untuk sembuh pada penyalahguna narkoba yaitu dengan kategori ya sebanyak $(66 \%)$ dan untuk kategori tidak sebanyak $(34 \%)$. hasil uji penelitian chi square dengan nilai $p=0,002$ artinya terdapat hubungan antara dukungan keluarga dengan keinginan untuk sembuh pada penyalahguna napza di Lembaga Pemasyarakatan Wirogunan Kota Yogyakarta.

Hasil penelitian yang serupa yang dilakukan oleh Lastari (2013) dengan judul hubungan antara faktor penyebab dengan kekambuhan pada penyalahguna narkoba di Yayasan Maha Kasih Kuningan tahun 3013 dengan menggunakan uji korelasi rank spearman di dapatkan hasil penelitian sebagi berikut, distribusi sikap keluarga penyalahguna narkoba dengan kategori mendukung sebanyak (85,2\%) dan untuk dukungan keluarga dengan kategori tidak mendukung sebanyak (14,8\%) sedangkan distribusi 
frekuensi kekambuhan sebanyak $(48,1 \%)$ dan tidak kambuh sebanyak (51,9\%). hasil uji penelitian dengan menggunakan uji korelasi rank spearman dengan nilai $p=$ 0,000 dengan nilai korelasi spearman $r=$ 0,651 . Hal ini dapat menunjukan bahwa terdapat hubungan yang bermakna antara faktor keluarga dengan kekambuhan pada penyalahguna narkoba di yayasan maha kasih kuningan.

Penelitian yang dilakukan oleh Nasron (2015) dengan judul Hubungan Antara Dukungan Keluarga Terhadap Kejadian Pada Ketergantungan Napza Di Yayasan Lantera Minangkabau Tahun 2015. Penelitian menggunakan chi square menunjukan distribusi frekuensi lebih dari setengahnya $(53,7 \%)$ responden mengalami ketergantungan terhadap napza dan lebih dari setengahnya responden tidak mendapat dukungan keluarga $(51,2 \%)$ dan hasil uji chi square menunjukan terdapat hubungan antara dukungan keluarga terhadap kejadian pada ketergantungan napza di yayasan lantera minangkabau tahun 2015 dengan nilai $p=0,000$

\section{SIMPULAN}

Berdasarkan pembahasan yang telah di uraikan pada bab sebelumnya, maka penelitian ini dapat disimpulkan sebagai berikut:

1. Sebagian besar penyalahguna narkoba yang berada di Rumah Damping Tenjo Laut Kabupaten Kuningan memiliki dukungan keluarga yang baik yaitu sebesar $(52,5 \%)$.

2. Sebagian besar penyalahguna narkoba yang berada di Rumah Damping Tenjo Laut Kabupaten Kuningan tidak mengalami kekambuhan (relapse) yaitu sebanyak (65\%).

3. Terdapat hubungan yang positif antara dukungan keluarga dengan kejadian kekambuhan pada penyalahguna narkoba di Rumah Damping Tenjo Laut Kabupaten Kuningan tahun 2016 ( $p$ value 0,026$)$.

\section{SARAN}

1. Bagi Pengguna Narkoba

Penyalahguna narkoba disarankan menghindari narkoba dan berusaha terus untuk hidup sehat tanpa narkoba, serta dapat pencegah terjadinya kekambuhan dengan cara melukan berbagi hal yang positif seperti melakukan ibadah kepada tuhan, melakukan bakti sosial, turut berperan aktif dalam pencegahan penyalahgunaan narkoba dengan lembaga yang terkait hal tersebut, dan bergaul dengan orang yang akan menjauhkan diri dari penyalahgunaan narkoba.

2. Bagi Keluarga

Keluarga disarankan lebih meningkatkan dukungan terhadap anggota keluarganya, keluarga juga harus tetap menjaga komunikasi dengan baik agar masing-masing anggota keluarga merasa nyaman saat mengungkapkan hal yang tidak sesuai dengan keinginannya. Selain itu, keluarga terutama orang tua harus selalu mendukung setiap aktivitas yang dapat membangun karakter positif, serta selalu memberikan dukungan emosional seperti kasih sayang dan perhatian. Keluarga tidak meninggalkan anak ketika berda dalam masalah namun membimbing dan tidak meninggalkan kewajibannya untuk mengingatkan anak saat melakukan kesalahan.

3. Bagi STIKes Kuningan

Diharapkan STIKes Kuningan dapat bekerjasama dalam menerapkan Tri Dharma Perguruan Tinggi berupa memerangi penyalahgunaan narkoba, membantu proses rehabilitasi kepada pengguna narkoba yang ingin pulih, melakukan upaya promosi kesehatan kepada 
masyarakat untuk tidak menggunakan narkoba, tidak mendiskriminasi para penyalahguna narkoba yang berada di masyarakat, dan diharapkan dapat membentuk kader anti narkoba.

4. Bagi Rumah Damping Tenjo Laut Diharapkan penelitian ini bisa menjadi dasar dan bahan informasi dalam mencari serta merancang strategi, program, metode pasca rehabilitasi dalam menangani penyalahguna narkoba agar tidak menggunakan narkoba kembali setelah selesai masa rehabilitasi dan dikembalikan ke lingkungannya masing - masing.

\section{DAFTAR PUSTAKA}

Ali, Z. (2009). Pengantar Keperawatan Keluarga. Jakarta: EGC

Arikunto, S. (2013). Prosedur Penelitian: Suatu Pendekatan Praktik. Jakarta: Rineka Cipta.

Badan Narkotika Nasional Kabupaten Kuningan. (2012). Mahasiswa Dan Bahaya Narkotika.

Badan Narkotika Nasional Kabupaten Kuningan. (2009). Pencegahan Penyalahgunaan Narkoba Apa Yang Bisa Anda Lakukan.

Badan Narkotika Nasional Republik Indonesia. (2009). Advokasi Pencegahan Penyalahgunaan Narkoba. Jakarta.

Badan Narkotika Nasional Provindi Jawa Barat. (2015). Pencegahan Penyalahgunaan Narkoba Bagi Remaja.

Badriah, Dewi L. (2012). Metodologi Penelitian IImu-IImu Kesehatan. Bandung : Multazam.

Dion, Y. (2013). Asuhan Keperawatan Keluarga Konsep Dan Praktik. Yogyakarta: Nuha Medika.

Lastari, VF. (2013). Hubungan Antara Faktor Penyebab dengan Kekambuhan pada Penyalahguna Narkoba di Yayasan Mahakasih Kuningan tahun 2013. kuningan: Sekolah Tinggi Ilmu Kesehatan Kuningan. Tidak dipublikasikan

Murti, B. (2013). Desain Dan Ukuran Sampel Untuk Penelitian Kuantitatif Dan Kualitatif Di Bidang Kesehatan. Yogyakarta: Gadjah Mada University Press

Notoatmodjo, S. (2012). Metodologi Penelitian Kesehatan. Jakarta: Rineka Cipta.. (2010). Metodologi Penelitian Kesehatan. Jakarta : Rineka Cipta.

Pusat Terapi \& Rehabilitasi Badan Narkotika Nasional, 2006. Modul Pelatihan Petugas Rehabilitasi Sosial Dalam Pelaksanaan Program One Stop Center (OSC).

Setiadi. (2008). Konsep Dan Proses Keperawatan Keluarga. Jakarta: Graha IImu.

Setyowati Dan Murwani. (2008). Asuhan Keperawatan Keluarga. Jogjakarta: Mitra Cendikia.

Sugiyono. (2009). Metode Penelitian Kuantitatif Kualitatif Dan R\&D. Bandung: Alfabeta Bandung.

Hurriyati. (2010) Mengapa Pengguna Narkoba Pada Remaja Akhir Relapse (Online) Jurnal IImiah Humaniora Vol.1 No.2 Oktober 2010: $\quad 303-314 \quad$ Tersedia Http://Eprints.Binus.Ac.Id/13177/ (13 Maret 2016)

Isnaini. (2009). Hubungan Antara Dukungan

Keluarga Dengan Keinginan Untuk Sembuh Pada Penyalahguna Napza Di Lembaga Pemasyarakatan Wirogunan Kota Yogyakarta. (Online) Journal IImiah Kesmas Issn: 1978-0575 Tersedia Http://Journal.Uad.Ac.Id/Index.Ph $\mathrm{p} /$ Kesmas/Article/View/1080/Pdf (13 Maret 1016)

Nasron. (2015). Hubungan Antara Dukungan Keluarga Terhadap Kejadian Pada Ketergantungan Napza Di Yayasan Lantera Minangkabau Tahun 2015.2 (online). https://www.scribd.com/doc/2940 
75094/Jurnal-Skripsi-Nasron-

Dinata Jurnal Skripsi Nasron

Dinata - Scribd (9 juli 2016)

Phadli. (2015). Jumlah Pengguna Narkoba

Di Indonesia. (Online).

Http://Www.Kompasiana.Com/Ph

adli/Jumlah-Pengguna-Narkoba-

Di-

Indonesia_553ded8d6ea834b92b

f39b35 (12 Maret 2016)

Prasetyaningsih. (2008) Tesis Faktor Terjadinyan Kekambuhan Pada Penyalahguna Napza Paska Pengobatan Di Panti Pamardi Putra Mandiri-Semarang Jawa Tengah. (Online) Tersedia Http//Eprints.Undip.Ac.Id/14655/

(13 Maret 2016)

Presiden Republic Indonesia.(2009). Undang - Undang No.35 Tahun $2009 \quad$ Tentang Narkotika.(Online).Http//Bnn.Go.I d/Portal/_Uploads/Post/2014/09/0 3/Uu_No_35_Tahun_2009_Narko tika.Pdf (20 Januari 2016).

UNODC. (2012). United Nations on drugs and crime 2012 Tersedia Http://Www.Unodc.Org/Unodc/Da ta-And-Analysis/Wdr-2012.Html (21 Januari 2016).

WDR. (2012). World Drugs Report 2012 (Online) Tersedia Http:/Www.Unodc.Org/Unodc/Da ta-And-Analysis/Wdr-2012. Html (21 Januari 2016). 